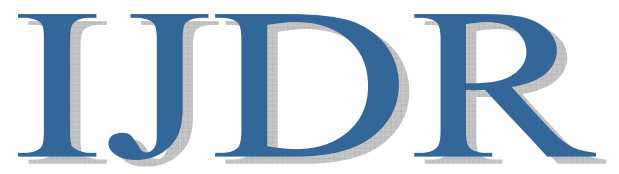

International Journal of Development Research

Vol. 10, Issue, 05, pp. 36171-36176, May, 2020

https://doi.org/10.37118/ijdr.18905.05.2020

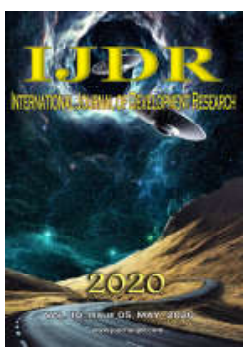

\title{
REDUCING THE ENVIRONMENTAL IMPACT WITH EMPHASIS ON THE USE OF PCR RESIN IN THE MANUFACTURE OF PREFORMS FOR PET PACKAGING
}

\section{${ }^{1}$ Marco Aurélio Da Silva Marques, ${ }^{1}$ Mauro Cezar Aparício de Souza, ${ }^{1}$ Alexandra Priscilla Tregue Costa, ${ }^{2}$ Marden Eufrasio dos Santos and ${ }^{* 2}$ David Barbosa de Alencar}

${ }^{1}$ Academic department, University Center FAMETRO, Amazon-Brazil

2Institute of Technology and Education Galileo of Amazon (ITEGAM), Brazil

\section{ARTICLE INFO}

\section{Article History:}

Received $17^{\text {th }}$ February, 2020

Received in revised form

$30^{\text {th }}$ March, 2020

Accepted $17^{\text {th }}$ April, 2020

Published online $30^{\text {th }}$ May, 2020

\section{Key Words:}

PET Packaging, Environmental Impact;

PET-PCR.

*Corresponding author:

David Barbosa de Alencar,

\begin{abstract}
The production of Polyethylene Terephthalate - PET has been one of the elements that cause concern in the modern industry to the environment, due to the disposal of the product discarded after use. This work shows the use of post-consumer resin (PCR) as one of the means to reduce the environmental impact generated by PET production. This process provides less carbon footprint, PET can be recycled several times before losing its properties, PCR adheres to a more sustainable and ecologically correct consumption, totally replaces Virgin PET resin and PET recycling reduces environmental impacts and contributes to the circular economy.
\end{abstract}

Copyright (C) 2020, Marco Aurélio Da Silva Marques et al. This is an open access article distributed under the Creative Commons Attribution License, which permits unrestricted use, distribution, and reproduction in any medium, provided the original work is properly cited.

Citation: Marco Aurélio Da Silva Marques, Mauro Cezar Aparício de Souza, Alexandra Priscilla Tregue Costa, Marden Eufrasio dos Santos and David Barbosa de Alencar. "Reducing the environmental impact with emphasis on the use of pcr resin in the manufacture of preforms for pet packaging", International Journal of Development Research, 10, (05), 36171-36176.

\section{INTRODUCTION}

O PET tornou-se um dos maiores poluidores do meio ambiente, pois assim como outros polímeros possuem um tempo elevadíssimo de degradação na natureza, cerca de 400 anos, podendo permanecer na natureza por até 800 anos para ser absorvido pelo meio ambiente. Só no Brasil em 2016 foram transformados 840.000tons em produto acabado (ABIPET 2008). Podemos afirmar que em 2016 foram lançadas 420.000tons de material poluidor oriundo do PET. Pois as taxas atuais de reciclagem do PET no Brasil estão por volta de 50\% (ABIPET 2008), ainda sim temos um volume enorme de embalagens tipo PET sendo lançadas todos os anos na natureza. Hoje o PET tem uma gama de utilização muito extensa, não só na indústria de alimentos, mas como também na indústria farmacológica, indústria de cosméticos e várias outras indústrias. Nos alimentos sua utilização vai desde uso nas embalagens de bebidas carbonatadas e não carbonatadas, como para isotônicos, bebidas lácteas, óleo, azeite, maioneses, catchup e muito mais.
As vantagens de se utilizar as embalagens de PET? O PET tem inúmeras vantagens em relação as embalagens oriundas do vidro e metal. Uma das maiores vantagens é sua concepção do produto, a fabricação da embalagem PET tem o custo menor que os outros tipos de embalagens, a versatilidade do PET é uma outra vantagem, é de fácil moldagem podendo ser concebido para praticamente qualquer tipo de produto. A aparência também é um ponto chave desse tipo de embalagem, é transparente é brilhante, podendo ser adicionado vários tipos de pigmento para a embalagem se adequar ao produto final. A resistência do PET é outro fator importante, o PET é praticamente inquebrável, se tornando uma embalagem segura para o manuseio em todas as faixas etária. As empresas transformadoras de resina PET em pré-forma para serem sopradas e transformadas em embalagens para alimentos, estão trabalhando para reduzir o impacto ambiental. Será mostrado como uma das maiores multinacionais na produção de préforma e embalagem tipo PET, Amcor Embalagens da Amazonia S/A, está trabalhando para reduzir o impacto ambiental em $20 \%$ no seu processo de transformação de embalagem com auxílio da utilização da resina pós consumo (PCR). 


\section{REFERÊNCIAL TEÓRICO}

\section{O Que é oPET?}

O PET é um polímero, sendo um polímero é extraído do petróleo, descoberto na década de 30 , sua utilização desde sua descoberta cresce a cada ano na indústria moderna, na indústria têxtil, embalagens, filmes e no setor automobilístico. $\mathrm{O}$ direcionamento de sua aplicação é de acordo com o percentual de viscosidade intrínseca (VI), que é o que mede a resistência mecânica, química e térmica da resina. Quanto maior o VI, maior a resistência mecânica, químico e térmica. FORMIGONI (2007), mostra as vantagens da utilização do PET. A resina PET com VI acima de 0,7 é utilizada nas embalagens de bebidas carbonatadas. A resina PET com VI abaixo de 0,7 é utilizada na indústria têxtil, filmes e outros tipos de embalagens. Os estudos para diversificar sua utilização continuam intensos para diversificar sua utilização.

Injeção Plástica: A injeção plástica consiste na transformação do polímero, que chamamos de resina em produto acabado. Existe vários métodos de injeção plástica, para diferentes polímeros, más todos os métodos passam por quatro etapas distintas, secagem, plastificação, injeção e moldagem. Embora a tecnologia para a produção de PET esteja relativamente madura, os melhoramentos continuam. Uma variedade de catalisadores tem sido usada nas etapas de processo de esterificação e condensação na fase líquida. Novas composições de catalisadores têm sido desenvolvidas num esforço de melhorar a eficiência do processo e diminuir os resíduos de catalisadores (Montenegro, 1996, pag. 65). SECAGEM DA RESINA: Considerada uma das etapas importante do processo de injeção plástica, pois é nessa etapa que a resina é aquecida e retirada a umidade, que influencia diretamente na viscosidade intrínseca (VI), que é responsável pelas propriedades mecânicas, químicas e térmicas da resina. PLASTIFICAÇÃO: Na plastificação a resina é transformada do estado sólido para o líquido através de aplicação de calor por meio de resistência elétrica. A resina para passar do estado sólido para o estado líquido recebe uma temperatura entre $275^{\circ} \mathrm{C}$ a $300^{\circ} \mathrm{C}$. essa temperatura depende do tipo de polímero que está sendo injetado. INJEÇÃO: Na etapa de injeção a resina já está no estado líquido, ou seja, já está plastificada e através de uma rosca sem fim e um cilindro de injeção da resina. Alguns polímeros na transformação em produto acabado não necessita da próxima etapa, mas como a grande utilização do polímero PET é na transformação em embalagens, é necessário a quarta etapa que a moldagem.

MOLDAGEM: Na etapa de moldagem a resina é injetada em estado líquido em um molde com desenho pré-defino para sua utilização, no molde a resina é resfriada e solidificada a baixa temperatura estando pronta para ser utilizada.

Resina Pós Consumo (PCR): A injeção de corpos de prova a partir de garrafas moídas mostrou-se altamente produtiva, com níveis aceitáveis até o quarto passo, o que pode ser um indicativo que, para produtos $100 \%$ reciclados, a extrusão de "pellets" que se faz intermediariamente, pode ser eliminada. A mistura de flocos de garrafa com grânulos do material virgem para se obter produtos com propriedades mais próximas da virgem não é muito indicada para ser feita diretamente em injetora, pela diferença de densidade dos dois tipos de PET (Bezerra, 2013). HENTOUX (2018), mostra as vantagens da reciclagem do PET PCR.
Segundo (Oliveira, 2012), demanda crescente por esses produtos resultam no significativo aumento de geração de resíduos plásticos. As disposições e tratamentos mais adequados são o reuso, redução, reciclagem, incineração e, por último, aterros. Entretanto, sem que haja uma gestão adequada, a maioria desses resíduos é enviada para aterros ou lixões, ou dispostos irregularmente no ambiente, prejudicando a vida e a saúde de animais e dos seres humanos.

Impacto Ambiental Industrial: A reciclagem das embalagens pós consumo, é um tema abordado pelos ambientalistas, questionando as empresas e os governantes sobre quais as medidas devem ser adotadas para que no futuro não se tenha que conviver num caos ambiental, social e no meio do lixo. Ou seja, as embalagens quando consumidas de maneira exagerada e descartada de forma regular ou irregular podem contribuir para o esgotamento dos aterros sanitários. (UDA, 2010)

Ferramenta para Análise de Dados, Pareto: Segundo (Ramos, 2013), o gráfico de Pareto e um método gráfico de apresentação de dados por ordem de tamanho, importância ou prioridade, como uma forma de classificar os problemas relativos a qualidade em "poucos vitais" e "muito triviais". Os poucos vitais são aqueles problemas que causam grande números de perdas ou defeitos, ou seja, aqueles problemas que afetam grandemente a qualidade, ao passo que muitos triviais são aqueles problemas que afetam pouco a qualidade dos produtos ou serviços.

\section{METODOLOGIA}

Neste artigo abordará o tema da diminuição do impacto ambiental com a utilização da resina pós consumo (PCR). Foram utilizados dados quantitativos e qualitativos de produção de pré-forma para fabricação de embalagens tipo PET, os dados de KPI's foram cedidos pela empresa Amcor Embalagens da Amazonia S/A. Os dados se referem a produção no ano fiscal de 2018/2019, no qual serão mostrados na planilha e gráfico. Com auxílio de planilha e do gráfico será mostrado a evolução do empenho para se reduzir o impacto ambiental ocasionado pelo uso de embalagens tipo PET, com a adição de $20 \%$ de resina pós consumo (PCR). Através dos dados coletados será criado o gráfico de pareto para análise dos dados coletados.

\section{APLICAÇÃO DO ESTUDO}

Fluxo do Processo com Resina Virgem: Na figura - 01 temos o fluxograma das etapas do processo de injeção plástica sem adição de resina PCR.

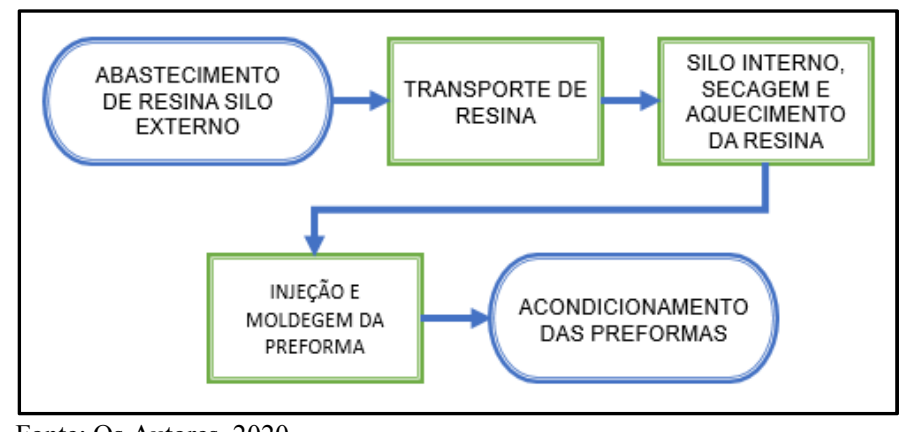

Fonte: Os Autores, 2020.

Fig. 1. Fluxograma do processo de PCR 
O processo somente com resina virgem funciona conforme o fluxograma acima. A resina é abastecida o silo externo através de um sistema vácuo, após o armazenamento conforme a demanda da resina durante o processo produtivo a mesma é transportada para o silo interno para ser preparada para o consumo, em sua preparação é retirada a umidade e aquecida, o tempo necessário para a preparação, é denominado TEMPO DE RESIDÊNCIA. Após a preparação a resina está pronta para injeção, moldagem e acondicionamento do produto final.

\section{Processo Produtivo de Pré-Forma com Resina PET} Virgem: O processo produtivo de pré-formas com resina PET virgem possuem quatro etapas, que veremos a seguir:

- Abastecimento da resina;

- Armazenamento da resina em silos externos;

- $\quad$ secagem e aquecimento da resina em silos internos;

- Injeção e moldagem das pré-formas

Abastecimento da Resina: O abastecimento é feito através de um sistema de vácuo, onde uma bomba de vácuo transporta a resina do contêiner na figura 2, através de duto até os silos externos para ser armazenada.

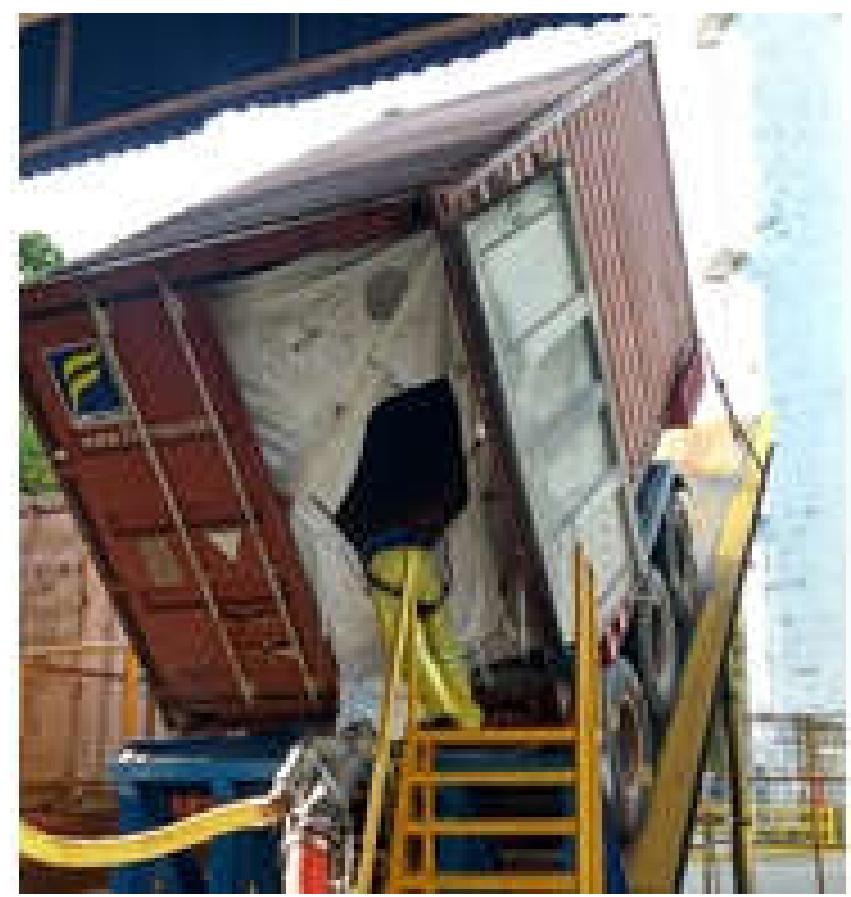

Fonte: Os Autores, 2020

Fig. 2. Bomba de abastecimento da resina.

Armazenamento da Resina em Silos Externos: Os silos externos nafigura 3, após abastecido com resina virgem, ficam aguardando a programação para o consumo dessa resina. A empresa Amcor possui atualmente três silos externos para armazenamento de resina virgem, cada silo tem a capacidade armazenar 350tons.

Secagem e Aquecimento da Resina em Silos Internos: Para a resina PET possa ser transformada em produto final, as préformas, é necessário que a mesma esteja com o nível de umidade adequado, assim como tem que estar aquecida a uma temperatura apropriada para a transformação, essa etapa acontece quando a resina é transportada para os silos internos ver Figura 4.

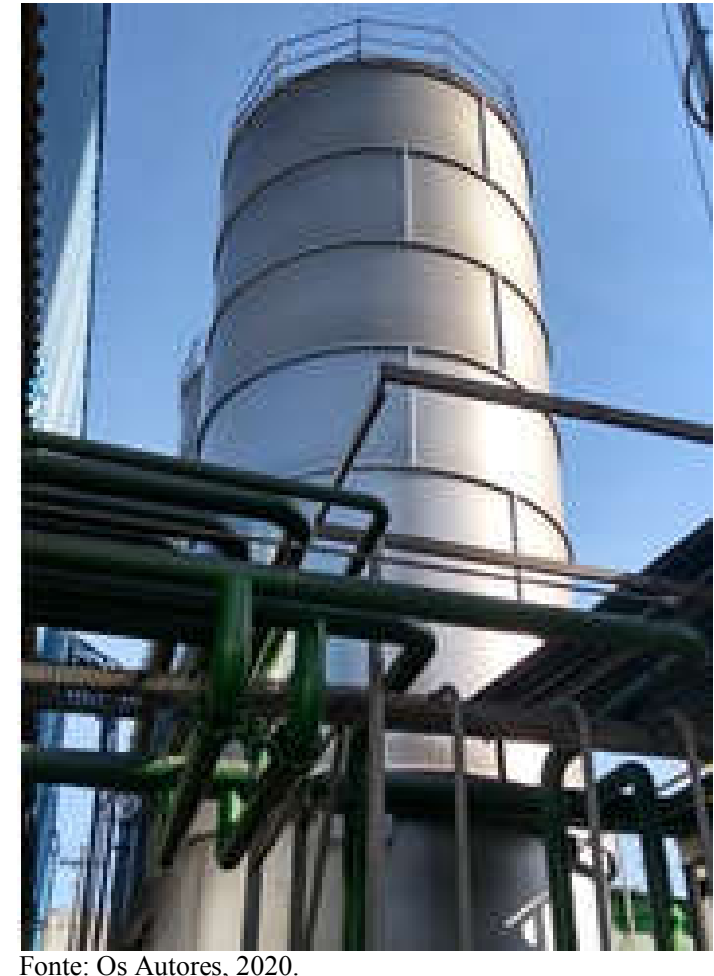

Fig. 3. Silos externos de armazenagens

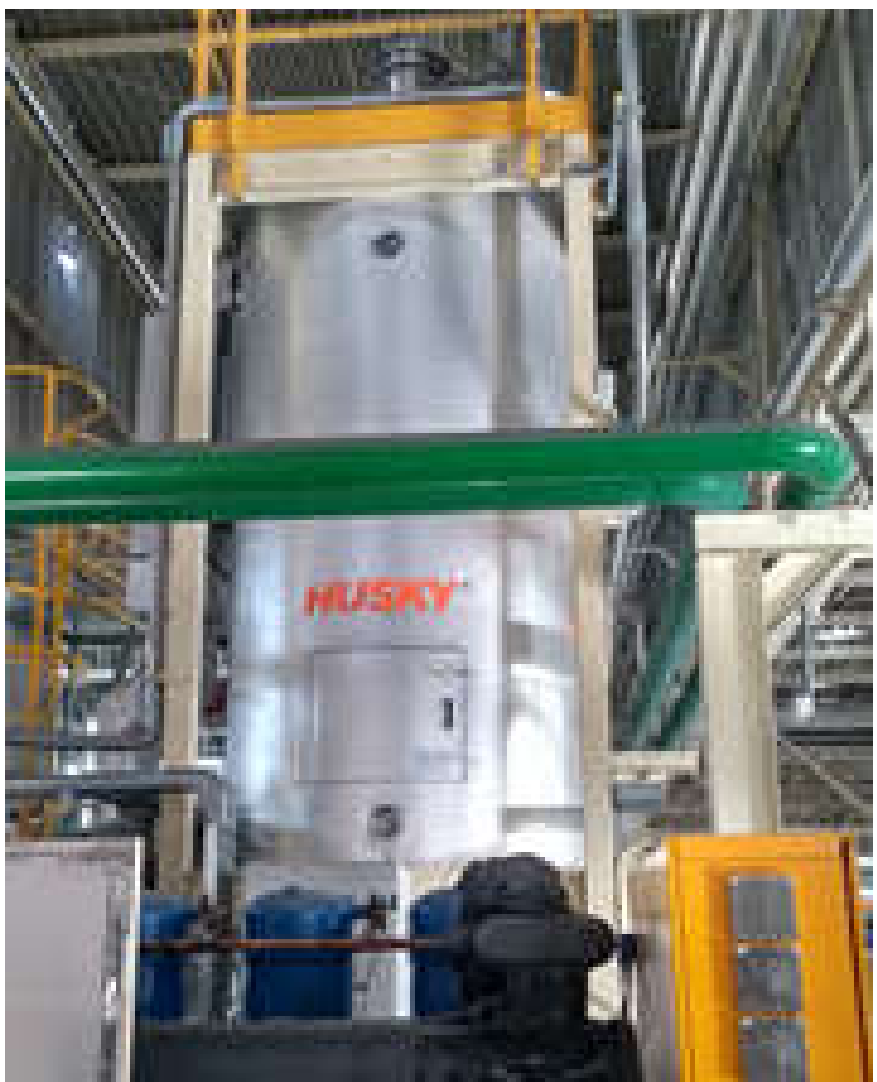

Fonte: Os Autores, 2020

Fig. 4. Silo interno de aquecimento.

Após é feita a retirada a umidade e aquecida pelo equipamento denominado de desumidificador de matéria-prima, ver figura 5. Para que a resina PET possa estar dentro de um padrão adequado para a transformação, há um tempo de permanência dentro dos silos internos, esse tempo é denominado de tempo residência. 


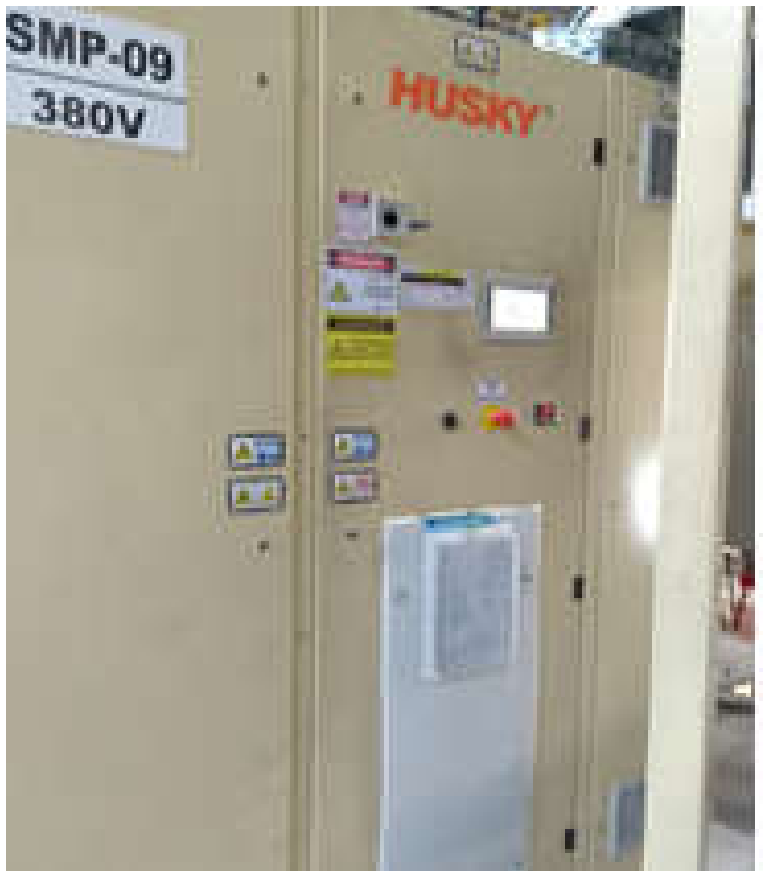

Fonte: Os Autores, 2020.

Fig. 5. Desumidificador de matéria-prima

O tempo de residência é calculado de acordo com a gramatura das pré-formas e a capacidade do equipamento de transformação.

Injeção e Moldagem das Pré-Formas: Após a retirada da umidade e aquecimento da resina PET com o tempo de residência adequado, a mesma está pronta transformação, ou seja, para ser injetada e moldada. $\mathrm{O}$ equipamento responsável pela injeção e moldagem é denominado de injetora, ver figura 6.

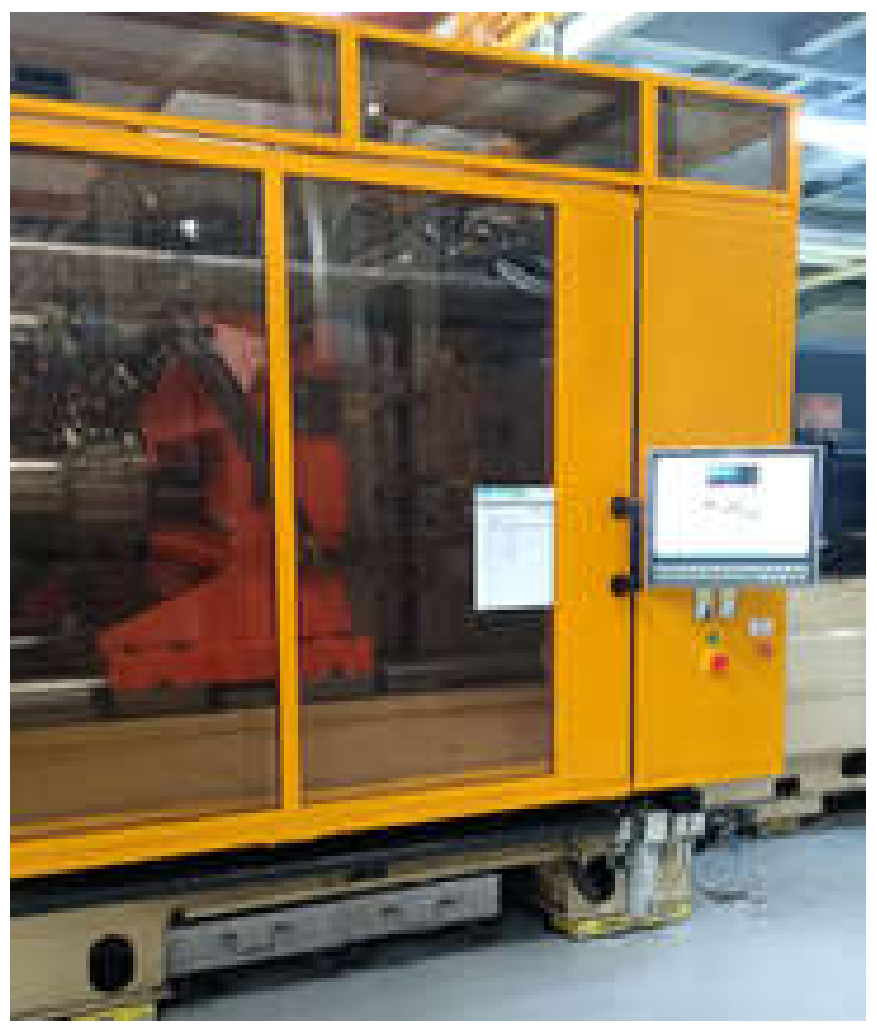

Fonte: Os Autores, 2020.

Fig. 6. Injetora de molde
A injetora é dividida basicamente em pelo menos duas partes, a injeção e a moldagem. $\mathrm{Na}$ injeção a injetora possui um canhão que é composto de uma rosca sem fim e várias resistências que aquecem o canhão a uma temperatura entre $280^{\circ} \mathrm{C}$ a $300^{\circ} \mathrm{C}$, temperatura suficiente para transformar a resina do estado sólido para o estado líquido, ver Figura 7.

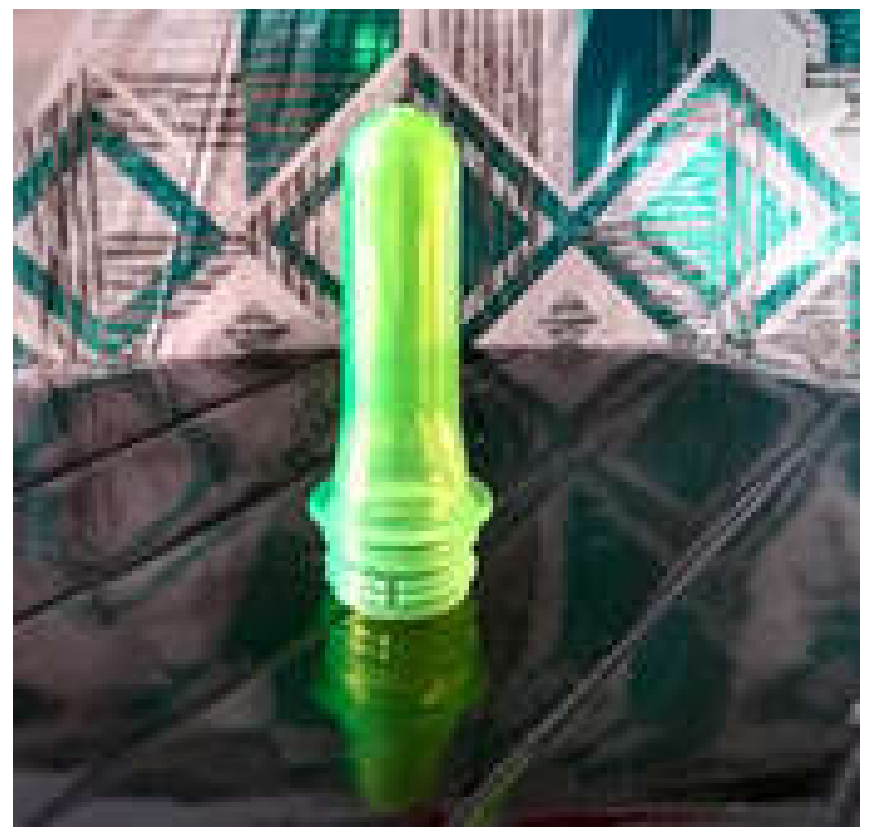

Fonte: Os Autores, 2020.

Fig. 7. Molde PET pré-forma

Após a resina ser transformada em estado líquido, a mesma é injetada dentro de um molde bipartido, onde moldado o produto final, a pré-forma.

Fluxo do Processo com Adição de Resina PCR: Na figura 8 temos o fluxograma das etapas do processo de injeção plástica com adição de resina PCR.

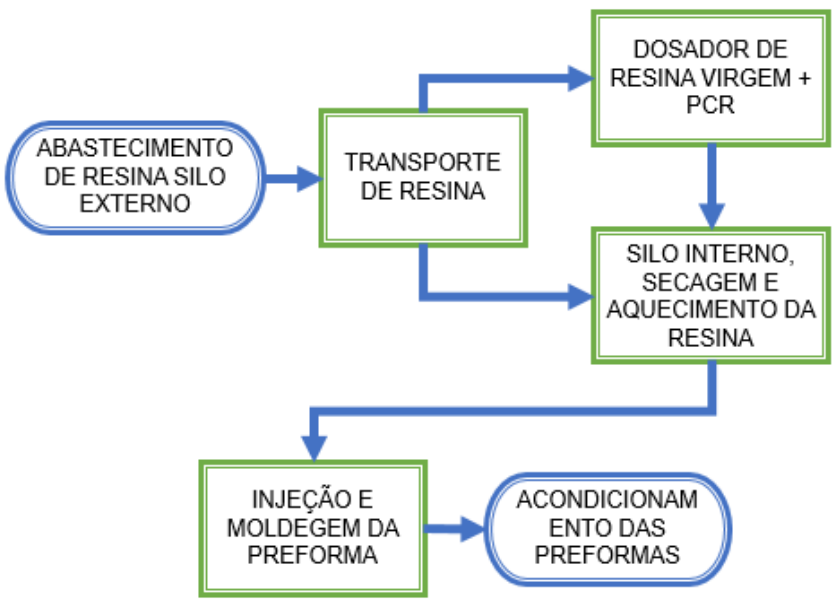

Fonte: Os Autores, 2020.

Fig. 8. Fluxograma com resina PCR.

O processo com adição de resina PCR é basicamente o mesmo processo da resina virgem, há somente uma única diferença, que é a blendagem da virgem com a resina PCR, essa blendagem é feita através de um equipamento chamado de dosador gravimétrico, o restante processo segue o mesmo da resina virgem. 
Processo Produtivo de Pré-Forma com Resina PET PCR: O processo produtivo de pré-formas com resina PET pós consumo PCR possuem cinco etapas, ou seja, uma etapa a mais que o processo com a resina virgem:

Abastecimento da resina;

- Armazenamento da resina em silos externos;

- Dosagem da resina pós consumo PCR

- Secagem e aquecimento da resina em silos internos;

- Injeção e moldagem das pré-formas.

Dosagem Da Resina Pós Consumo PCR: Como as quatro etapas que já vimos no processo com resina virgem são similares ao processo com resina pós consumo PCR, vamos apenas descrever a etapa diferenciada no processo da resina pós consumo do PCR. Para a etapa de dosagem da resina pós consumo da resina PCR é feito pelo equipamento denominado dosador gravimétrico, o equipamento é configurado conforme a dosagem necessária para o processo, no nosso caso, $80 \%$ de resina virgem com adição de $20 \%$ de resina pós consumo PCR, ver Figura 9

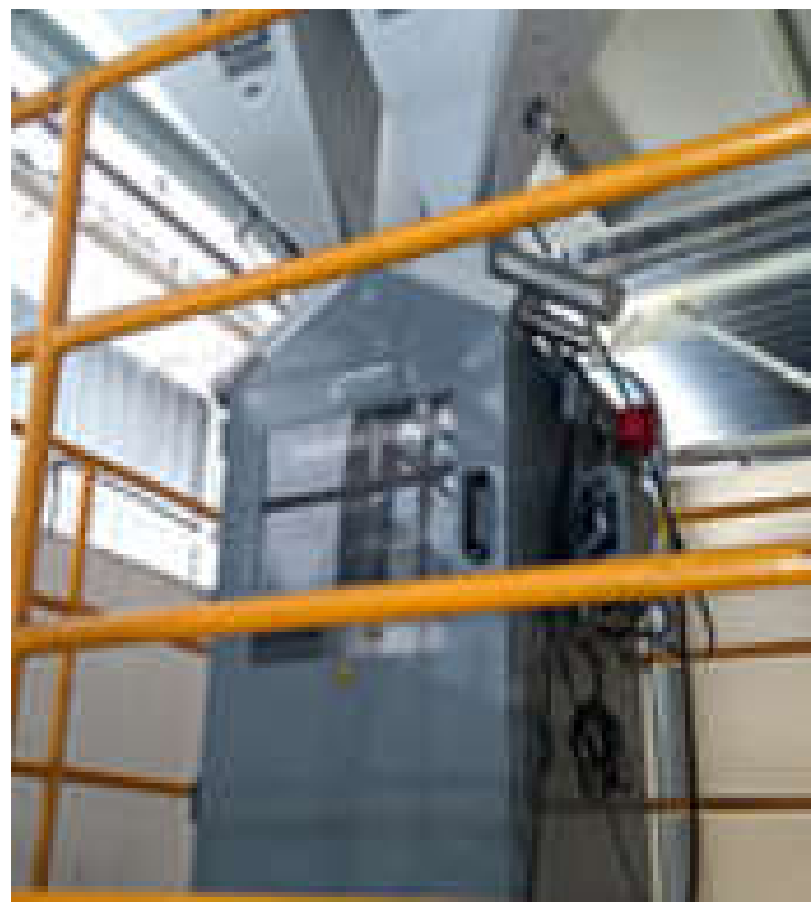

Fonte: Os Autores, 2020

Fig. 9. Dosador gravimétrico

Tab. 1. KPI Injeção - Amcor Manaus - Brasil (2018/2019)

\begin{tabular}{|c|c|c|c|c|c|c|}
\hline $\begin{array}{c}\text { Ano } \\
\text { Fiscal }\end{array}$ & Mês & $\begin{array}{c}\text { Produção } \\
\text { Atual } \\
\text { (MM) }\end{array}$ & $\begin{array}{l}\text { PCR } \\
\text { Prod. } \\
(\mathrm{MM})\end{array}$ & $\begin{array}{c}\text { Total de } \\
\text { resina }\end{array}$ & $\begin{array}{c}\% \\
\text { Resina } \\
\text { Virgem }\end{array}$ & $\begin{array}{c}\% \\
\text { Resina } \\
\text { PCR }\end{array}$ \\
\hline \multirow{5}{*}{$\stackrel{\infty}{0}$} & Jul & 108,40 & 1,13 & 109,53 & 98,97 & 1,03 \\
\hline & Ago & 135,52 & 1,22 & 136,74 & 99,11 & 0,89 \\
\hline & Set & 132,04 & 0,62 & 132,66 & 99,53 & 0,47 \\
\hline & Out & 120,47 & 1,86 & 122,33 & 98,48 & 1,52 \\
\hline & Nov & 129,91 & 1,11 & 131,02 & 99,15 & 0,85 \\
\hline \multirow{8}{*}{$\frac{\curvearrowright}{\circ}$} & Dez & 148,75 & 2,00 & 150,75 & 98,67 & 1,33 \\
\hline & Jan & 146,00 & 2,06 & 148,06 & 98,61 & 1,39 \\
\hline & Fev & 137,40 & 1,59 & 138,99 & 98,86 & 1,14 \\
\hline & Mar & 147,94 & 1,70 & 149,64 & 98,86 & 1,14 \\
\hline & Abr & 150,78 & 2,02 & 152,80 & 98,68 & 1,32 \\
\hline & Mai & 154,16 & 2,14 & 156,30 & 98,63 & 1,37 \\
\hline & Jun & 128,44 & 1,34 & 129,78 & 98,97 & 1,03 \\
\hline & $\sum$ Ano & 1639,65 & 18,79 & 1658,44 & 98,87 & 1,13 \\
\hline
\end{tabular}

Fonte: Os Autores, 2020.
A tabela1 refere-se ao consumo de resina virgem e resina PCR durante o ano fiscal de 2018/2019, que compreende de julho a junho dos respectivos anos. O volume de consumo de resina, ou seja, a produção de pré-forma é de acordo com a previsão de vendas da empresa, para cada mês há um volume a ser produzido conforme a demanda dos clientes. Mas o fato é que todos os meses do ano fiscal 2018/2019, foi utilizado um volume aparentemente considerado pequeno de resina PCR.

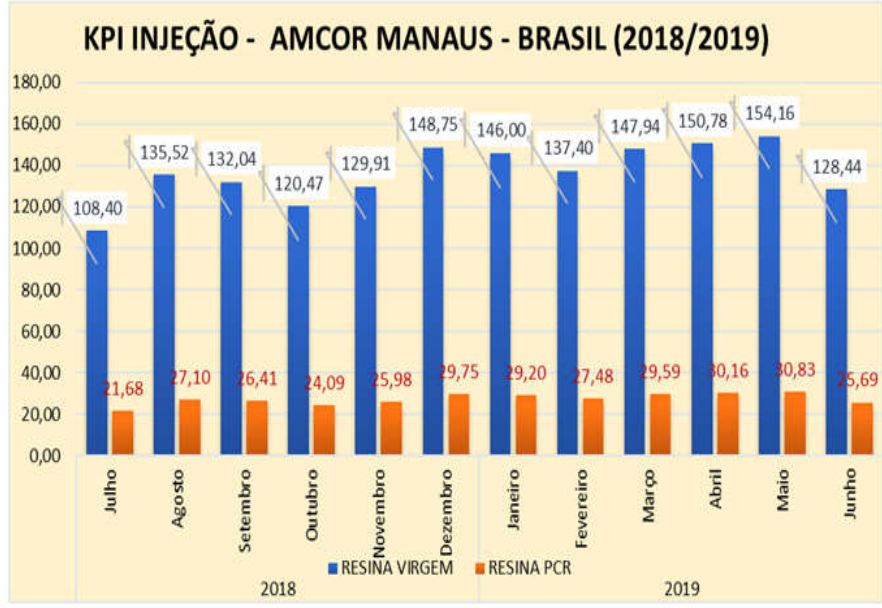

Fonte: Os Autores, 2020

Gráfico 1. KPI INJEÇÃO - AMCOR MANAUS - BRASIL (2018/2019)

\section{Conclusão}

Ainda há muito que se fazer em que se refere ao impacto ocasionado pelo homem na natureza, por isso as iniciativas devem partir de todos nós. Pois não devemos esperar que as ações partam somente das grandes empresas, governos, fundação e etc. Nós temos que tentar resolver esse problema com grandes e pequenas ações, com alta tecnologia ou de maneira simples. A resina PCR mostra vantagens significativas quanto a reciclagem dos PETs e também no processo de produção.

\section{REFERÊNCIAS}

AMCOR EMBALAGENS DA AMAZONIA (2019). Manaus AM. Disponível em: $<$ http://www.amcor.com.br $>$. Acesso em: 25/08/2019.

ABIPET (2008). São Paulo - SP. Disponível em: $<$ http://www.abipet.org.br>. Acesso em: 02/09/2019.

BRASKEM (2018). São Paulo - SP. Disponível em: $<$ http://www.braskem.com.br>. Acesso em: 18/09/2019.

BEZERRA, Maxwell N.; MANCINI, Sandro D.; ZANIN, Maria. Reciclagem de PET advindo de garrafas de refrigerante pós-consumo. Polímeros: ciência e tecnologia, v. 8, n. 2, p. 68-75, 2013.

FORMIGONI, A.; CAMPOS, IP de A. Reciclagem de PET Bottle-to-Bottle. In: 1 st International Workshop Advances in Cleaner Production, São Paulo, UniversidadePaulista. 2007.

HENTOUX, Miguel Ângelo. Análise da cadeia de valor da reciclagem de PET com ênfase no PET-PCR grau alimentício. 2018.

DE OLIVEIRA, M. C. B. R. Gestão de resíduos plásticos pósconsumo: perspectivas para a reciclagem no Brasil. Maria Clara Brandt Ribeiro de Oliveira-Rio de Janeiro: UFRJ/COPPE, 2012. 
UDA, Marcos Junitsi. Logística reversa da reciclagem de garrafas PET em Curitiba. 2011. Tese de Doutorado. Dissertação de mestrado). Instituto de Tecnologia para o Desenvolvimento (LACTEC), Curitiba.
MONTENEGRO, Ricardo Sá Peixoto; MONTEIRO FILHA, Dulce Corrêa; PAN, Simon ShiKoo. Resina PET para recipientes. 1996.

RAMOS, Edson MLS; DE ALMEIDA, Silvia dos Santos; DOS REIS ARAÚJO, Adrilayne. Controle estatístico da qualidade. Bookman, 2013. 